\title{
PENGARUH PENGGUNAAN MEDIA TEKNOLOGI INFORMASI DAN KOMUNIKASI (TIK) DENGAN PRESTASI BELAJAR BAHASA INGGRIS PESERTA DIDIK KELAS X DI SMAN I DEKAI KABUPATEN YAHUKIMO
}

\author{
Yusri \\ yusri.acho@yahoo.com \\ Fakultas Teknik Universitas Pejuang Republik Indonesia (UPRI)
}

\begin{abstract}
Abstrak
Penelitian ini bertujuan Untuk mengetahui penggunaan media Teknologi Informasi Komunikasi peserta didik, Untuk mengetahui tingkat penguasaan media Teknologi Informasi Komunikasi para pendidik dalam memotivasi Peserta didik dan Untuk mengetahui hubungan penggunaan media Teknologi Informasi Komunikasi dengan motivasi belajar peserta didik kelas X SMA Negeri I Dekai Kabupaten Yahukimo. Hasil penelitian menunjukkan Bahwa penggunaan Teknologi Informasi Komunikasi (TIK) Peserta didik berada pada kategori tinggi. (66,67\%). Artinya bahwa penggunaan TIK memiliki manfaat yang sangat besar terhadap peningkatan penguasaan media internet para pendidik dalam memotivasi Peserta didik kelas X SMA Negeri I Dekai Kabupaten Yahukimo. Bahwa tingkat prestasi belajar bahasa inggris Peserta didik berada pada kategori tinggi. $(53,34 \%)$ artinya bahwa selama ini peningkatan penguasaan media internet para pendidik dalam memotivasi Peserta didik kelas X SMA Negeri I Dekai Kabupaten Yahukimo adalah dengan gairah, semangat, dan keinginan untuk mempelajari media Teknologi Informasi Komunikasi tersebut. Penggunaan TIK mempunyai hubungan yang kuat dengan peningkatan penguasaan media internet para pendidik dalam memotivasi Peserta didik. Hal ini ditandai dengan nilai koefisien korelasi $R=0,861$ (mendekati nilai angka 1). Artinya semakin diterpa penggunaan TIK pada mata pelajaran Bahasa Inggris maka semakin kuat peningkatan penguasaan media internet para pendidik dalam memotivasi Peserta didik kelas X SMA Negeri I Dekai Kabupaten Yahukimo tersebut.
\end{abstract}

Kata Kunci: Manfaat Media TIK, Prestasi Belajar.

\section{(i) (2)}

c.

\section{Pendahuluan}

Era globalisasi membawa pengaruh pada segenap aspek kehidupan manusia. Hal ini dapat dilihat dari prosesnya yang berada dalam sebuah sistem yang saling mempengaruhi antara satu orang atau kelompok tertentu. Oleh karenanya mereka tidak berjalan dalam ruang hampa dan kosong karena saling membutuhkan. Begitu pula pengaruh antara pendidikan dengan perkembangan sosialbudaya, termasuk ilmu pengetahuan dan teknologi yang terjadi di lingkungannya. Sistem pendidikan dipengaruhi oleh perubahan yang terjadi di masyarakat, sebaliknya pendidikan juga mempengaruhi dan bahkan diharapkan dapat mengarahkan perubahan dalam masyarakat agar terjadi ke arah yang positif. Salah satu perubahan besar yang terjadi dalam beberapa dasawarsa terakhir ini, adalah kemajuan Teknologi Informasi dan Komunikasi (TIK), yang didukung oleh penggunaan komputer. Dengan kemajuan TIK, maka terjadilah era globalisasi yang merambah pada aspek sosial budaya, politik, ekonomi, termasuk pendidikan. Berkembangnya TIK telah mengubah pola-pola komunikasi dan distribusi informasi tanpa batas wilayah, Negara, atau waktu dan ruang. Dalam kaitannya dengan proses pembelajaran Bahasa Inggris di sekolah, TIK khususnya belum dapat dimanfaatkan oleh pendidik maupun peserta didik, antara lain dalam pencarian informasi atau bahan pelajaran, mendekatkan jarak ruang dan waktu dalam interaksi pendidik-peserta didik, efisiensi pembelajaran serta penyimpanan berbagai data dan informasi yang diperlukan.

Pemanfaatan TIK dalam pembelajaran Bahasa Inggris tentu tergantung pada kemampuan dan kreativitas pendidik dalam mengoperasikan media pembelajaran tersebut. Menurut [1] menyatakan bahwa dengan menggunakan media pembelajaran dengan efektif dan kontinyu akan dapat mempengaruhi prestasi peserta didik di dalam kelas/sekolah. Hal ini disebabkan karena kemajuan IPTEK telah membawa banyak manfaat untuk mengembangkan sebuah pembelajaran dengan desain atau metode yang cocok dengan keinginan dan selera peserta didik. Dalam hal ini sebagai salah satu sekolah yang diharapkan dapat berkembang dan menerima setiap perubahan khususnya dalam Teknologi Informasi dan Komunikasi di masa yang akan datang. Maka SMA Negeri 1 Dekai Kabupaten Yahukimo sebagai salah satu sekolah yang mencermati perkembangan TIK tersebut sangat sadar akan hal ini, sehingga sebagai manifestasinya berusaha menata kurikulum sekolah yang berbasis muatan lokal dan tetap bertindak global dalam mengadopsi bentuk - bentuk inovasi pendidikan. Berdasarkan latar belakang masalah di atas, maka rumusan masalah ini 
penelitian ini adalah bagaimanakah penggunaan media Teknologi Informasi dan Komunikasi (TIK), bagaimanakah tingkat prestasi belajar, dan apakah ada pengaruh penggunaan media Teknologi Informasi dan Komunikasi terhadap prestasi belajar Bahasa Inggris peserta didik kelas X di SMA Negeri 1 Dekai Kabupaten Yahukimo. Berdasarkan rumusan masalah di atas, maka tujuan yang ingin dicapai dalam penelitian ini adalah untuk mengetahui penggunaan media Teknologi Informasi dan Komunikasi (TIK), Untuk mengetahui tingkat prestasi belajar, dan Untuk mengetahui pengaruh penggunaan media Teknologi Informasi dan Komunikasi terhadap prestasi belajar Bahasa Inggris peserta didik kelas $X$ di SMA Negeri 1 Dekai Kabupaten Yahukimo. Kegunaan penelitian ini yang pertama diharapkan dapat mengetahui penggunaan media Teknologi Informasi dan Komunikasi (TIK), diharapkan dapat mengetahui tingkat prestasi belajar, dan diharapkan dapat mengetahui pengaruh penggunaan media Teknologi Informasi dan Komunikasi terhadap prestasi belajar Bahasa Inggris peserta didik kelas $X$ di SMA Negeri 1 Dekai Kabupaten Yahukimo. Manfaat yang ke dua diharapkan menjadi bahan referensi dalam rangka pengembangan ilmu komunikasi dan teknologi, diharapkan menjadi bahan informasi bagi para peneliti yang berminat mengembangkan kajian yang relevan dengan hasil penelitian ini, dan diharapkan mampu memberikan bahan masukan bagi Dinas Pendidikan untuk pengembangan teknologi Informasi dan komunikasi dalam dunia pendidikan, terutama pada mata pelajaran Bahasa Inggris.

\section{Landasan Teori}

\subsection{Komunikasi dan Pendidikan}

Komunikasi dapat berhasil dengan baik apabila timbul saling pengertian atau pemahaman antara sesama manusia, baik sebagai pihak komunikator (pengirim pesan) maupun sebagai pihak komunikan (penerima pesan). Secara etimologi, komunikasi berasal dari bahasa Latin, communicatio. Perkataan ini bersumber dari kata "communi" yang berarti sama, yaitu sama makna mengenai suatu hal. Sebagaimana yang dijelaskan Schramm [2] bahwa:

Communication berasal dari kata komuni yang berarti sama. Jika mengadakan komunikasi dengan semua pihak, maka gagasan dinyatakan untuk memperoleh persamaan makna dengan pihak lain mengenai suatu objek tertentu.

Selanjutnya menurut Verderber [3] mengemukakan bahwa "komunikasi yang efektif adalah komunikasi yang memungkinkan makna yang disampaikan mirip atau sama dengan makna yang dimaksudkan komunikator. Singkatnya komunikasi yang efektif adalah makna bersama".

\subsection{Teknologi Komunikasi Pembelajaran}

Hewitt (1981), menjabarkan tujuan penggunaan proses komunikasi secara spesifik sebagai berikut: Mempelajari atau mengajarkan sesuatu, Mempengaruhi perilaku seseorang, Mengungkapkan perasaan, Menjelaskan perilaku sendiri atau perilaku orang lain, Berhubungan dengan orang lain, Menyelesaikan sebuah masalah, Mencapai sebuah tujuan, Menurunkan ketegangan dan menyelesaikan konflik, Menstimulasi minat pada diri sendiri atau orang lain.

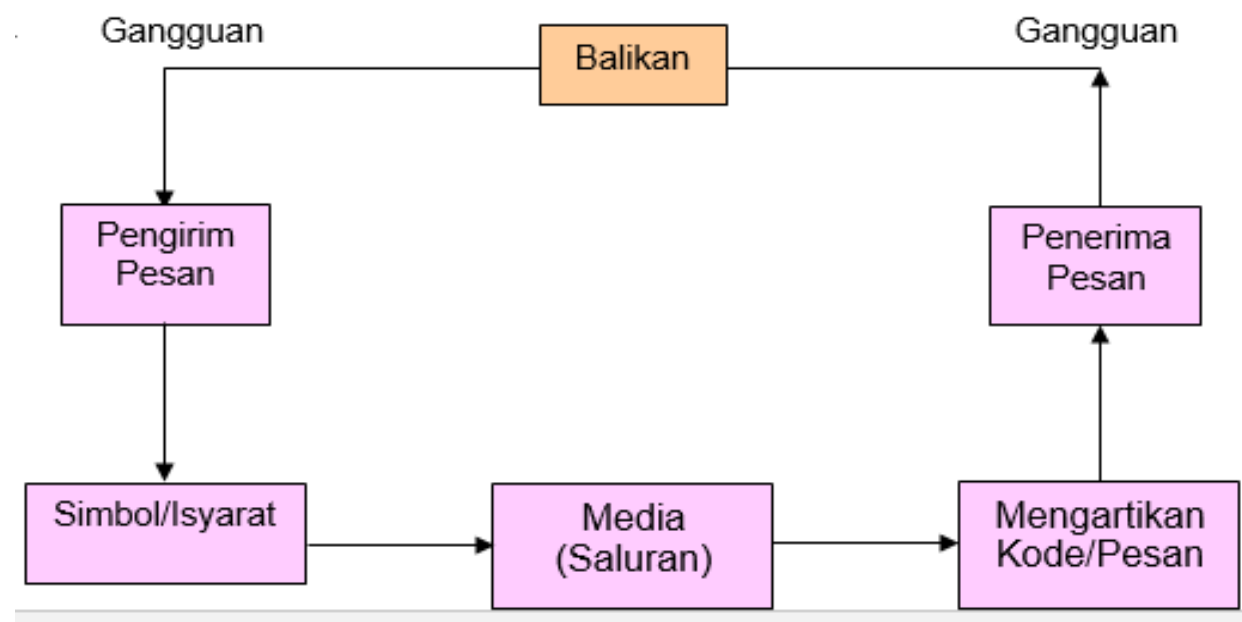

Gambar 1. Diagram Proses Komunikasi

\subsection{Penggunaan TIK Dalam Pembelajaran Bahasa Inggris}




\section{Pengertian Teknologi}

Menurut Vaza [5] teknologi adalah sebuah proses yang dilaksanakan dalam upaya mewujudkan sesuatu secara rasional. Vaza menekankan kata rasional dalam pengertian teknologi tersebut.

\section{Pengertian Teknologi Pendidikan dan Pembelajaran}

Teknologi pendidikan bisa dipandang sebagai suatu produk dan proses [6] Sebagai suatu produk, teknologi pendidikan mudah dipahami karena sifatnya lebih kongkrit seperti radio, televisi, proyektor, OHP, dan sebagainya. Sebagai sebuah proses, teknologi pendidikan bersifat abstrak. Dalam hal ini teknologi pendidikan bisa dipahami sebagai suatu proses yang kompleks dan terpadu yang melibatkan orang, prosedur, ide, peralatan, dan organisasi untuk menganalisis masalah, mencari jalan untuk mengatasi permasalahan, melaksanakan, menilai, dan mengelola pemecahan masalah tersebut yang menyangkut semua aspek belajar manusia (AECT, 1977). Sejalan dengan hal tersebut, maka lahirlah teknologi pendidikan dari adanya permasalahan dalam pendidikan. Ada tiga prinsip dasar dalam teknologi pendidikan sebagai acuan dalam pengembangan dan pemanfaatannya, yaitu pendekatan sistem, berorientasi pada siswa, dan pemanfaatan pada sumber belajar [5].

\section{Teknologi Informasi dan Komunikasi dalam Pembelajaran}

Saat ini perkembangan teknologi informasi $(\mathrm{TI})$ telah memberikan pengaruh terhadap dunia pendidikan khususnya dalam proses pembelajaran. Menurut Rosenberg (2001), dengan berkembangnya penggunaan TI ada lima pergeseran dalam proses pembelajaran yaitu: (1) dari pelatihan ke penampilan, (2) dari ruang kelas ke di mana dan kapan saja, (3) dari kertas ke "on line" atau saluran, (4) fasilitas fisik ke fasilitas jaringan kerja, dan (5) dari waktu siklus ke waktu nyata.

\subsection{Prestasi Belajar Bahasa Inggris}

Menurut Poerwadarmita [7] mengemukakan bahwa "prestasi" adalah hasil yang dicapai, dilakukan dan dikerjakan, tinggi rendahnya suatu nilai sebagai hasil yang dicapai oleh seseorang. Sedangkan Suryabrata [8] bahwa "Prestasi" mewujudkan kecakapan suatu manusia dan suatu bangsa.

Sahabuddin mengemukakan bahwa Belajar dapat didefinisikan sebagai suatu proses kegiatan yang menimbulkan kelakuan baru atau merubah kelakuan lama sehingga seseorang lebih mampu memecahkan masalah dan menyesuaikan diri terhadap situasi-situasi. [9]

Pengertian prestasi belajar juga dikemukakan oleh Mudjijana [10] yang mengatakan prestasi belajar adalah hasil yang dicapai seorang siswa berupa penambahan atau peningkatan kualitas perilaku dari rana konigtif, afektif dan psikomotorik yang dicapai melalui aktivitas siswa dalam proses belajar mengajar.

Selanjutnya Winkel [11] mengatakan bahwa "prestasi belajar adalah suatu bukti keberhasilan belajar atau kemampuan seseorang siswa dalam melakukan kegiatan belajarnya sesuai dengan bobot yang dicapainya." Sedangkan menurut S. Nasution [1996:17] prestasi belajar adalah: "Kesempurnaan yang dicapai seseorang dalam berfikir, merasa dan berbuat.

\section{Metode Penelitian}

\subsection{Pendekatan dan Desain Penelitian}

a. Pendekatan Penelitian

Penelitian ini menggunakan pendekatan deskriptif kuantitatif, yaitu mengkaji keterkaitan antara dua variabel, yaitu Pengaruh TIK dan prestasi belajar.

b. Desain Penelitian

Penelitian ini menggunakan desain korelasional dimaksudkan untuk melihat pengaruh antara variabel bebas, TIK $(\mathrm{X})$ dengan variabel terikat prestasi belajar $(\mathrm{Y})$, untuk lebih jelasnya, berikut desain penelitian.

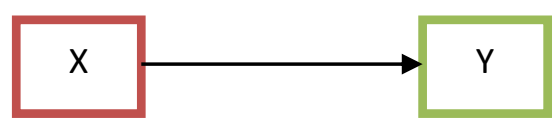

Keterangan: $X=T I K ; Y=$ dan prestasi belajar Bahasa Inggris peserta didik Kelas $X$

\subsection{Populasi dan Sampel}

a. Populasi

Pengertian populasi adalah suatu yang menjadi sasaran penelitian dalam usaha memperoleh informasi dan menarik kesimpulan. Populasi penelitian ini adalah keseluruhan siswa kelas X IImu Sosial I yang mengikuti mata pelajaran Bahasa Inggris diSMAN I Dekai Kabupaten Yahukimo sebanyak 125 orang. 


\section{b. Sampel}

Ukuran sampel ditentukan dengan mengambil sebanyak $25 \%$ dari jumlah populasi, pengambilan $20 \%$ dari ukuran sampel sejalan dengan pendapat [12] bahwa: .... apabila sudah kurang dari 100 orang maka lebih baik diambil semua sehingga penelitiannya merupakan penelitian populasi. Selanjutnya jika jumlah subyeknya besar dapat diambil antara $10-15 \%$ atau $20-25 \%$ dari jumlah populasi. Dalam penelitian ini maka jumlah sampel adalah 30 orang peserta didik.

\subsection{Teknik Pengumpulan Data}

Teknik pengumpulan data yang digunakan adalah beberapa metode, dengan maksud agar kelemahan dan keterbatasan setiap metode dapat ditutupi oleh metode lain.

1. Angket

Yaitu sejumlah daftar pertanyaan yang digunakanuntuk memperoleh data dan informasi dari responden pertanyaan-pertanyaan tersebut disusun sedemikian rupa berdasarkan indikator yang ada

2. Wawancara

Yaitu kegiatan wawancara langsung kepada kepala sekolah dan pendidik, yang terkait dengan penelitianya itu keadaan peserta didik kelas X SMAN 1 Dekai Kabupaten Yahukimo.

\subsection{TeknikAnalisis Data}

Untuk menjawab permasalahan dalam penelitian ini, maka teknik analisis data yang digunakan adalah analisis deskriptif dan análisis inferensial.

Untuk keperluan análisis deskriptif digunakan karakteristik nilai tertinggi, nilai terendah, mean, median, modus, distribusi frekuensi, persentase, dan histogram.

Sedangkan pedoman pengkategorian yang digunakan untuk mengelompokkan strategi komunikasi kepala sekolah dan kinerja pendidik berpedoman pada penilaian acuan patokan dari Arikunto (1993:48), yaitu:

Tabel 1. Penilaian Acuan Patokan

\begin{tabular}{ll} 
Interval Nilai & Kategori \\
\hline & \\
$8,1-10,0$ & Sangat tinggi \\
$6,6-8,0$ & Tinggi \\
$5,6-6,5$ & Sedang \\
$4,1-5,5$ & Rendah \\
$0,0-4,0$ & Sangat rendah \\
\hline
\end{tabular}

Selanjutnya analisis statistik inferensial digunakan untuk menguji hipotesis penelitian yang telah diajukan. Pengujian hipotesis tersebut dimaksudkan untuk mengetahui ada tidaknya pengaruh penggunaan TIK terhadap prestasi belajar Bahasa Inggris peserta didik kelas X di SMAN I Dekai Kabupaten Yahukimo, berdasarkan nilai koefisien korelasi (r).

Untuk maksud tersebut, maka nilai koefisien korelasi $(r)$ dapat dihitung dengan menggunakan persamaan koefisien korelasi product moment, menurut Arikunto (1993:206) sebagai berikut:

$$
r=\frac{n \sum X_{i} \cdot Y_{i}-\left(\sum X_{i}\right)\left(\sum Y_{i}\right)}{\sqrt{\left\{n \sum X^{2}-\left(\sum X_{i}\right)^{2}\right\}\left\{n \sum Y_{i}^{2}-\left(\sum Y_{1}\right)^{2}\right\}}}
$$

Keterangan:

$\mathrm{r}_{\mathrm{xy}}=$ Koefisien korelasi antara variabel $\mathrm{X}$ dan variabel $\mathrm{Y}$.

$\mathrm{X} \quad=$ Penggunaan $\mathrm{TIK}$

$\mathrm{Y}=$ Prestasi belajar Bahasa Inggris peserta didik kelas X Di SMAN I Dekai Kabupaten

Yahukimo

$\mathrm{n} \quad=$ Jumlah sampel

Kriteria yang digunakan untuk menginterpretasi nilai kuatnya hubungan antara kedua variabel adalah seperti yang dikemukakan oleh Tiro (2000: 48), sebagai berikut:

Tabel 2. Konversi nilai kualitatif nilai IKH. 


\begin{tabular}{ll}
\hline Nilai IKH & Hubungan \\
\hline $0,80-1,00$ & Sangat kuat \\
$0,60-0,79$ & Kuat \\
$0,40-0,59$ & Sedang \\
$0,20-0,39$ & Lemah \\
$0,00-0,19$ & Sangat lemah \\
\hline
\end{tabular}

\section{Hasil}

Penggunaan media teknologi informasi dan komunikasi peserta didik Pada Mata Pelajaran Bahasa Inggris Kelas X di SMAN 1 Dekai Kabupaten Yahukimo Provinsi Papua. Bila melihat realitas jawaban setiap responden dapat dikatakan bahwa penggunaan media teknologi informasi dan komunikasi peserta didik kelas X di SMAN I Dekai terhadap peserta didik sangat bagus. Hal ini ditandai dengan lebih dari $50 \%$ responden memberikan jawaban sangat menarik penggunaan media teknologi informasi dan komunikasi peserta didik kelas X di SMAN I Dekai Kabupaten Yahukimo.

Tingkat prestasi belajar Bahasa Inggris peserta didik kelas X di SMAN I Dekai Kabupaten Yahukimo Dalam sebuah hasil belajar peserta didik maka peningkatan dari setiap akhir sementer selalu diharapkan. Sebagaimana tingkat prestasi belajar Bahasa Inggris peserta didik kelas $X$ di SMAN I Dekai Kabupaten Yahukimo. Maka berikut ini penulis akan mentabulasikan jawaban sesuai dengan pertanyaan yang diberikan kepada peserta didik mereka sebagai berikut:

Tabel 3.Distribusi responden berdasarkan peningkatan prestasi belajar dengan penggunaan media teknologi informasi dan komunikasi peserta didik kelas $X$ di SMN I Dekai Kabupaten Yahukimo

\begin{tabular}{llll}
\hline No & Alternatif Jawaban & Jumlah Responden & $\begin{array}{l}\text { Jumlah } \\
(\%)\end{array}$ \\
\hline 1 & Sangat meningkat & 17 & 56,66 \\
2 & Meningkat & 3 & 10,0 \\
3 & Biasa & 5 & 16,66 \\
4 & Tidak meningkat & 1 & 3,33 \\
5 & Sangat tidak meningkat & 4 & 13,33 \\
& Total & 30 & $100 \%$ \\
\hline
\end{tabular}

Pada tabel di atas menunjukkan bahwa dari 30 orang yang ditetapkan menjadi responden dalam penelitian ini, masing-masing mempunyai jawaban alternatif dalam menjawab pertanyaan tentang peningkatan prestasi belajar dengan penggunaan media teknologi informasi dan komunikasi peserta didik kelas X di SMAN I Dekai Kabupaten Yahukimo. Pada tabel di atas terlihat bahwa 17 orang responden atau $56,66 \%$ yang memberikan jawaban sangat meningkat prestasi belajar dengan penggunaan media teknologi informasi dan komunikasi peserta didik kelas $X$ di SMAN I Dekai Kabupaten Yahukimo, kemudian sekitar 3 orang atau 10,0\% yang memberi jawaban meningkat, kemudian ada 5 orang atau 16,66\% yang memberi jawaban biasa. Kemudian hanya 1 orang atau $3,33 \%$ yang memberikan jawaban tidak meningkat. Dan sisanya sebesar 4 orang atau 13,33\% yang memberikan jawaban bahwa sangat tidak meningkat penggunaan media teknologi informasi dan komunikasi peserta didik kelas X di SMAN I Dekai Kabupaten Yahukimo.

Melihat jumlah responden yang memberikan jawaban sangat menarik penggunaan media teknologi informasi dan komunikasi peserta didik kelas X di SMAN I Dekai Kabupaten Yahukimo, berarti memberikan penguatan bahwa hampir lebih $50 \%$ peserta didik mampu meningkatkan prestasi belajar Bahasa Inggris mereka. Sehingga dengan demikian memberi penguatan dan harapan pendidik sebagai bagian strategi komunikasi yang akan dilakukan pada SMAN I Dekai Kabupaten Yahukimo dalam meningkatkan prestasi belajar tersebut. Penggunaan media teknologi informasi dan komunikasi peserta didik kelas $X$ di SMAN I Dekai Kabupaten Yahukimo sangat berpotensi untuk memberikan contoh dan menularkannya kepada semua stakeholder yang ada di SMAN I Dekai Kabupaten Yahukimo. Untuk menganalisis data dalam penelitian ini, maka penulis menggunakan rumus."r". Product moment. Adapun rumusnya adalah sebagai berikut:

$$
r_{x y}=\frac{N \sum X Y-\left(\sum X\right)\left(\sum Y\right)}{\sqrt{\left[N \sum X^{2}-\left(\sum X\right)^{2}\right]\left[N \sum Y^{2}-\left(\sum Y\right)^{2}\right]}}
$$

Keterangan:

Rxy = Angka Indeks Korelasi .r. product moment (variabel $x$ dan y) 


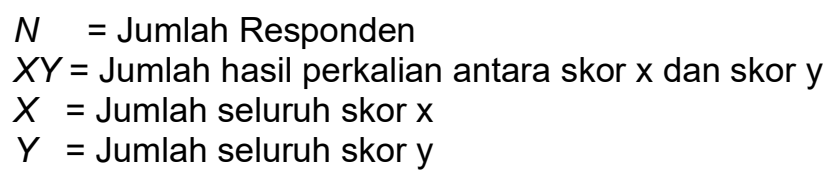

Indikator-indikator yang dipergunakan untuk mengukur adanya hubungan atau pengaruh antara variabel dependen prestasi belajar Bahasa Inggris peserta didik kelas X di SMAN I Dekai Kabupaten Yahukimo (Y) dengan variabel independen penggunaan media teknologi informasi dan komunikasi $(\mathrm{X})$. Tetapi seberapa besar hubungan tersebut, belum dapat diketahui.

Oleh karena itu, untuk mengetahui ada tidaknya pengaruh atau korelasi dan arah Pengaruh penggunaan media teknologi informasi dan komunikasi terhadap prestasi belajar Bahasa Inggris peserta didik kelas X di SMAN I Dekai Kabupaten Yahukimo, diperlukan analisis lebih lanjut tentang arah hubungan dari masing-masing variabel tersebut. Sehingga, untuk menjawab persoalan tersebut dipergunakan analisis regresi linier sederhana atau analisis korelasi product moment.

Hipotesis penelitian ini berbunyi: "Ada pengaruh yang kuat penggunaan media teknologi informasi dan komunikasi terhadap prestasi belajar Bahasa Inggris peserta didik kelas $X$ di SMAN I Dekai Kabupaten Yahukimo."

Pengujian hipotesis penelitian ini dilakukan dengan menggunakan teknik uji regresi linier sederhana atau analisis korelasi product moment. Berdasarkan hasil analisis regresi linier sederhana tersebut, pasangan data prestasi belajar Bahasa Inggris peserta didik kelas X di SMAN I Dekai Kabupaten Yahukimo $(Y)$ dengan variabel independen penggunaan media teknologi informasi dan komunikasi $(\mathrm{X})$, diketahui bahwa nilai koefisien regresi b yang diperoleh adalah sebesar 0,108 dan nilai konstanta sebesar 4,502. Dari uraian tersebut, maka dapat dijelaskan persamaan regresi antara variabel penggunaan media teknologi informasi dan komunikasi terhadap prestasi belajar Bahasa Inggris peserta didik kelas X di SMAN I Dekai Kabupaten Yahukimo adalah $Y=4,502+0,108 X$.

Tabel 4. Uji-t, Uji Signifikansi prestasi belajar Bahasa Inggris peserta didik kelas X di SMAN I Dekai Kabupaten Yahukimo (Y) dengan variabel independen penggunaan media teknologi informasi dan komunikasi $(\mathrm{X})$

\begin{tabular}{lllllll}
\hline \multirow{2}{*}{ Model } & \multicolumn{2}{l}{$\begin{array}{l}\text { Unstandardized } \\
\text { Coefficients }\end{array}$} & \multicolumn{2}{l}{$\begin{array}{l}\text { Standardized } \\
\text { Coefficients }\end{array}$} & & \\
\cline { 2 - 4 } & $\mathrm{B}$ & Std. Error & Beta & t-hitung & t-tabel & Sig. \\
\hline 1 (Constant) & 4,502 & 0,485 & & 9,290 & & 0,000 \\
X & 0,108 & 0,018 & 0,861 & 6,114 & 1,75 & 0,000
\end{tabular}

a Dependent Variable: $Y$

Selanjutnya, untuk melihat penggunaan media teknologi informasi dan komunikasi terhadap prestasi belajar Bahasa Inggris peserta didik kelas X di SMAN I Dekai Kabupaten Yahukimo dapat diketahui berdasarkan besarnya nilai $R$ Square (koefisien determinasi) sebagaimana terlihat pada tabel sebagai berikut:

Tabel 5. $R$ Square $\left(r^{2}\right)$, Besarnya tingkat pengaruh penggunaan media teknologi informasi dan komunikasi terhadap prestasi belajar Bahasa Inggris peserta didik kelas X di SMAN I Dekai Kabupaten Yahukimo

\begin{tabular}{lll}
\hline Model & $\mathrm{R}$ & $\mathrm{R}$ Square \\
\hline 1. & 0,861 & 0,742 \\
\hline
\end{tabular}

Tabel tersebut di atas menunjukkan bahwa besarnya pengaruh penggunaan media teknologi informasi dan komunikasi terhadap prestasi belajar Bahasa Inggris peserta didik kelas X di SMAN I Dekai Kabupaten Yahukimo adalah sebesar 0,742 atau sebesar 74,2\%. Artinya, bahwa sekitar 74,2\% perubahan kinerja pendidik di SMAN I Dekai Kabupaten Yahukimo dapat dijelaskan oleh variabel stategi komunikasi kepala sekolah (X), sedangkan sisanya sekitar 25,8\% disebabkan oleh faktor lain yang tidak dijelaskan dalam model ini. Sedangkan koefisien korelasi $R=0,861$, berarti korelasi antara penggunaan media teknologi informasi dan komunikasi terhadap prestasi belajar Bahasa Inggris peserta didik kelas X di SMAN I Dekai Kabupaten Yahukimo adalah sangat kuat.

\subsection{Pembahasan Hasil Penelitian}


Pengertian penggunaan media TIK di dalam penelitian ini adalah cara atau metode komunikasi yang dilakukan oleh seorang pendidik dalam memasukkan media teknologi pada setiap pembelajaran Bahasa Inggris di SMAN I Dekai Kabupaten Yahukimo, yang terdiri dari:

Kemudahan.

Sebagaimana pada hasil penelitian sebelumnya yang dimana sebahagian besar responden memberikan jawaban sangat mudah $(66,66 \%)$ hal ini menunjukkan bahwa apa yang dilakukan oleh pendidik di SMAN I Dekai kabupaten Yahukimo sangat baik dan tepat.

Masih menurut jalaluddin Rahmat selain persepsi interpersonal juga ada konsep diri yaitu pandangan dan perasaan kita tentang diri kita. Konsep diri yang positif, ditandai dengan lima hal, yaitu: a. Yakin akan kemampuan mengatasi masalah; b. Merasa setara dengan orang lain; $c$. Menerima pujian tanpa rasa malu; d. Menyadari, bahwa setiap orang mempunyai berbagai perasaan, keinginan dan perilaku yang tidak seluruhnya disetujui oleh masyarakat; e. Mampu memperbaiki dirinya karena ia sanggup mengungkapkan aspek-aspek kepribadian yang tidak disenanginya dan berusaha mengubah. Konsep diri merupakan faktor yang sangat menentukan dalam komunikasi persuasif, yaitu:

Membuat diri sendiri menjadi berarti, karena setiap orang bertingkah laku sedapat mungkin sesuai dengan konsep dirinya. Bila seseorang pendidik menganggap dirinya sebagai orang yang rajin, ia akan berusaha menghadiri pengajaran secara teratur, membuat catatan yang baik, mempelajari materi pelajaran dengan sungguh-sungguh, sehingga memperoleh nilai akademis yang baik.

Membuka diri. Pengetahuan tentang diri kita akan meningkatkan komunikasi, dan pada saat yang sama, berkomunikasi dengan orang lain meningkatkan pengetahuan tentang diri kita. Dengan membuka diri, konsep diri menjadi dekat pada kenyataan. Bila konsep diri sesuai dengan pengalaman kita, kita akan lebih terbuka untuk menerima pengalaman-pengalaman dan gagasan baru.

Percaya diri. Ketakutan untuk melakukan komunikasi dikenal sebagai communication apprehension. Orang yang aprehensif dalam komunikasi disebabkan oleh kurangnya rasa percaya diri. Untuk menumbuhkan percaya diri, menumbuhkan konsep diri yang sehat menjadi perlu.

Selektivitas. Konsep diri mempengaruhi perilaku komunikasi kita karena konsep diri mempengaruhi kepada pesan apa kita bersedia membuka diri (terpaan selektif), bagaimana kita mempersepsi pesan (persepsi selektif), dan apa yang kita ingat (ingatan selektif). Selain itu konsep diri juga berpengaruh dalam penyandian pesan (penyandian selektif).

Pada aspek kecepatan pada penggunaan media teknologi informasi dan komunikasi yang dilakukan oleh peserta didik kelas X di SMAN I Dekai Kabupaten Yahukimo cukup berhasil dari jumlah responden yang ditetapkan dalam penelitian ini terdapat 22 orang atau $73,33 \%$ responden yang memberikan jawaban bahwa peserta didik kelas X di SMAN I Dekai Kabupaten Yahukimo telah melakukan pengawasan sebagaimana hal perlu dilakukan oleh peserta didik. Dalam beberapa teori komunikasi bahwa kemudahan adalah bentuk respon sustanibility (keberlanjutan tanggapan) yang perlu disadari oleh pendidik.

Menurut asumsi peneliti berdasarkan hasil analisis deskriptif di atas, bahwa apabila kinerja pendidik mampu berkomunikasi aktif, taat/patuh, serta dapat bekerja sama maka sepertinya tidak ada lagi alasan untuk dapat meraih standar kinerja seperti yang diharapkan bersama.

\subsection{Hasil Analisis Regresi Linier Sederhana}

Untuk menguji hipotesis alternatif $\left(\mathrm{H}_{1}\right)$ penelitian ini yang berbunyi: "Ada hubungan yang sangat kuat antara penggunaan media teknologi informasi dan komunikasi terhadap prestasi belajar Bahasa Inggris peserta didik kelas X di SMAN I Dekai Kabupaten Yahukimo", maka dilakukan analisis statistik inferensial.

Kesimpulan yang dapat ditarik dari hasil analisis statistik inferensial dengan menggunakan teknik uji regresi linier sederhana dengan penerapan korelasi product moment menunjukkan bahwa penggunaan media teknologi informasi dan komunikasi terhadap prestasi belajar Bahasa Inggris peserta didik kelas X di SMAN I Dekai Kabupaten Yahukimo (X) mempunyai hubungan yang sangat kuat dengan penggunan TIK di SMAN I Dekai Kabupaten Yahukimo (Y) yang ditandai dengan nilai koefisien korelasi $\mathrm{R}=0,861$ (mendekati nilai angka 1) Hal ini berdasarkan tabel konversi kualitatif nilai Indeks Kuatnya Hubungan (IKH) yang dikemukakan oleh Tiro, 1999:48 sebagaimana telah diuraikan terdahulu.

\section{Kesimpulan dan Saran 5.1. Kesimpulan}


Hasil penelitian mengenai hubungan penggunaan media teknologi informasi dan komunikasi terhadap prestasi belajar Bahasa Inggris peserta didik kelas X di SMAN I Dekai Kabupaten Yahukimo, dapat disimpulkan sebagai berikut:

Bahwa penggunaan media teknologi informasi dan komunikasi di SMAN I Dekai Kabupaten Yahukimo berada pada kategori tinggi. (66,67\%) hal ini menegaskan bahwa penggunaan media teknologi informasi dan komunikasi melalui pendekatan kemudahan, kecepatan, efektif, efisien, dan ketertarikan akan berdampak baik terhadap prestasi belajar Bahasa Inggris peserta didik kelas X di SMAN I Dekai Kabupaten Yahukimo.

Bahwa tingkat prestasi belajar Bahasa Inggris peserta didik kelas $X$ di SMAN I Dekai Kabupaten Yahukimo berada pada kategori tinggi. (53,34\%) hal ini memberikan apresiasi dan keinginan oleh kepala sekolah bahwa dengan penerapan penggunaan media teknologi informasi dan komunikasi di SMAN I Dekai Kabupaten Yahukimo dengan melihat peningkatan hasil belajar mereka pada setiap akhir semester. Hubungan penggunaan media teknologi informasi dan komunikasi terhadap prestasi belajar Bahasa Inggris peserta didik kelas X di SMAN 1 Dekai Kabupaten Yahukimo sangat berpengaruh. Hal ini ditandai dengan nilai koefisien korelasi $\mathrm{R}=$ 0,861 (mendekati nilai angka 1), yakni besarnya hubungan penggunaan TIK dengan Tingkat prestasi belajar bahsa inggris peserta didik kelas X SMAN 1 Dekai.

\subsection{Saran}

Berdasarkan kesimpulan di atas, maka disarankan sebagai berikut:

Dengan diketahuinya bahwa penggunaan media teknologi informasi dan komunikasi di SMAN I Dekai Kabupaten Yahukimo berada pada kategori tinggi, maka pihak pengelolah, kepala sekolah bersama para pendidik hendaknya dapat mempertahankan dan menambah intensitas komunikasi yang dibangun dengan melakukan hal-hal antara lain sebagai berikut:

a. Mempertahankan dan menjaga hubungan antara kedua belah pihak yang sudah ada selama ini.

b. Menambah jumlah dan intensitas dalam pertemuan untuk berkomunikasi antara satu dengan yang lainnya.

Dengan diketahuinya bahwa prestasi belajar Bahasa Inggris peserta didik kelas X pada SMAN I Dekai Kabupaten Yahukimo berada pada kategori tinggi, maka kepala sekolah bersama para pendidik hendaknya berusaha terus untuk mempertahankan dan meningkatkan prestasi belajar Bahasa Inggris mereka dengan baik.

Disarankan kepada peneliti yang lain agar melakukan penelitian dengan kajian yang lebih mendalam dengan menambah faktor-faktor (variabel) lain yang diteliti.

\section{Daftar Pustaka}

[1] Budiman, Arif. 2010. Guru dalam Proses Belajar Mengajar. Bandung: Sinar Baru Algensindo.

[2] Sunaryo. 1995. Belajar dan Faktor-faktor yang Mempengaruhi Komunikator Dan Komunikan. Jakarta: Rineka Cipta.

[3] Effendy, Onong Uchajana, 2002. IImu Komunikasi Teori dan Praktek. Bandung: Remaja Rosdakarya. Cet. 13.

[4] Vaza. 2007. Pengantar Ilmu Komunikasi Dan Teknologi. Jakarta: PT. Rajagrafindo Persada.

[5] Sadiman. 1993, "Perkembangan Teknologi Informasi di Indonesia.“ Bandung: Pusat Penelitian informatika - LIPI.

[6] Petherbridge \& Chapmen. 2007. Teknologi Komunikasi \& Informasi Pembelajaran. Jakarta: Bumi Aksara.

[7] Murhani, Poewadarmita. 2003. Rahasia Sukses Membangun ESQ Dan Prestasi Belajar. Jakarta: Arga.

[8] Suryabrata. 2003. Psikologi Kognitif. Surabaya: Srikandi.

[9] Sahabuddin. 1999. Interaksi dan Motivasi Belajar Mengajar. Yogyakarta: Rajawali Press.

[10] Darmawati \& Mudjijana. 2008. Media Komunikasi Pendidikan. Jakarta: Bumi Aksara.

[11] Nasution. 1996. Metodologi Penelitian. Jakarta: PT. Bumi Aksara.

[12] Suharsimi, Arikunto. 2007. Prosedur Penelitian suatu Pendekatan Praktik. Jakarta: Rineka Cipta. 